\title{
CULTUROLOGY
}

\section{Ukrainian Famine through the prism of the modern world literature and journalism}

\author{
A. O. Roliak \\ State Agrarian and Engineering University in Podillia, Kamianets-Podilskyi, Ukraine \\ Corresponding author. E-mail: rolyakangel@gmail.com \\ Paper received 26.08.19; Accepted for publication 11.09.19.
}

\begin{abstract}
https://doi.org/10.31174/SEND-HS2019-205VII34-04
\end{abstract}
\begin{abstract}
The research is devoted to the Ukrainian famine background and its description in the world-famous masterpieces of prose and journalism. Based on the profound historical analysis of literature and documents from the world, European, Soviet and Ukrainian resources, the author investigates the main features of Stalin period in the European history that brought to a long-term negative effect on the liberalization of the Ukrainian society, education, and economy. The influence of negative effects of famine and terror on the mood of the people in the Ukrainian socio-economic space is grounded.
\end{abstract}

Keywords: Ukrainian famine, socialism, background, mass terror, repression, fascism, the Soviet Union.

Introduction. Stalin's period of repressions is multileveled. It embraced all the sides of the Soviet State: political, economic, cultural and educational ones. Moreover Stalin's government is considered to be the part of socialism construction and not only in the Soviet Union but in Europe too. In popular political discourse, socialism is portrayed as polar opposite to fascism [2]. Though fascism is placed on the far Right, socialism on the far Left. But a lot of historians think that this categorization is flatout wrong [4].

We regard Ukrainian femine as the planned part of Stalin's repression directed on the whole nation. Stalin repressions brought to a long-term negative effect on liberalization of the society and economy. In that period the democracy in America and most of European states started to evolve. Education, culture, entrepreneurship gradually transformed from elitism to accessibility for all [6;9]. But as for the Soviet Union it was led to a period of strict government control, mobilization, and terrorization of all its republics. Repressions were seen everywhere - in all the components of Soviet state. In the 1930s agriculture and industry suffered rude forced centralization. Cultural and educational activities in Ukraine were highly restricted too. In the result thousands of Soviet including Ukrainian educated, intelligent individuals deemed dangerous to the Stalin's Soviet state were eliminated [2]. Those who were nor repressed died in the result of "holodomor" - the major famine in Ukraine of 1932-1933 [5].

Brief overview of publications on the topic. Definition of Ukraine famine or (holodomor) as organized manmade process of inhabitants starvation in Ukrainian SSR is of concern to the entire world community today. The article presents analytical materials of Ukrainian scientists: Hrushevsky Mykhailo "A History of Ukraine" (1940), Hroch Miroslav "Comparative Studies in Modern European History: Nation,Nationalism, Social Change" (2007), Luciuk Lubomyr and Lisa Grekul "Holodomor: Reflections on the Great Famine of 1932-1933 in Soviet Ukraine" (2008), Kulchytskyi Stanislav "Holodomor in Ukraine 1932-1933: an Interpretation of Facts" (2012), Serbyn, Roman "The Holodomor: Genocide Against the Ukrainians" (2008), Szporluk Roman "Russia, Ukraine, and the Breakup of the Soviet Union" (2000) and also the world-known scholars: Andrew Wilson, Morgan Williams, Viola Lynne, David Roger Marples, Michael Dahlen, Anna Reid, David Marples, John A. Armstrong, Robert Williams Davies, Stephen G. Wheatcroft, Anne Applebaum, etc.

The purpose of research. The major objective of this study is to investigate and generalize the description of the Ukrainian famine in the world known historical and literature in context of European development in the early twenty-first century.

Methods. Data for this study were collected using the systematic, synergetic, culturological, axiological approaches to the historical analysis of social and philosophical phenomena. Basic information was gathered from multiple sources of the world, European and Ukrainian environments at various time points during 1930 till 2018. Application of dialectic, objective, continuity principles has made it possible to identify characteristic features of the Ukrainian famine and to explore how the process is described in the world literature and journalistic resources.

Results and discussion. As Michael Dahlen writes despite their superficial differences, fascism and socialism along with Nazism and theocracy - are fundamentally the same [3]. They are all examples of totalitarianism. These systems oppose freedom, liberty, and individual rights. They impose one-party rule, control or abolish private property, and censor or oppress racial, religious, political, and ideological enemies. They also seek to export their particular tyranny throughout the world. Whether the goal of a tyrant is achieving utopia, enforcing God's will, or establishing a master Aryan race, the results are always the same: purges and show trials, man-made famines and concentration camps, war and mass murder [3]. Socialism and Fascism represent the tyranny of Big Governments which are the main statist politico-economic systems.

From this point of view we want to analyze the studies of Anne Applebaum, who is a historian and journalist. She writes a lot of article for the Washington Post. She is a Professor of Practice at the London School of Economics. Since 1989 Anne has been writing about Eastern Europe and Russia, analyzing the collapse of communism in Poland for the Economics magazine. She also writes 
about US, UK and European politics for a wide range of American and British publications in addition to the Washington Post, including the New York Review of Books, the Spectator and Foreign Affairs. She is married to Radoslaw Sikorski, a Polish politician and writer, and lives in both Poland and Britain. Anne Applebaum is the author of several books, including "Gulag: a history", which won the 2004 Pulitzer Prize for non-fiction and "Iron Curtain", which won the 2013 Cundill Prize for Historical Literature. Both of these books were nominated for the National Book Award. Her newest book, Red Famine, describes the Ukrainian revolution of 1917 at the beginning, and continues with the Ukrainian famine of 1932-33. Most critics stress that this book provides the background to today's Russian-Ukrainian conflict.

In 1929 Stalin launched his policy of agricultural collectivization - in effect from the point of view of Ann Applebaum it brought to a second Russian revolution which forced millions of peasants off their land and into collective farms [1]. The result was the most lethal in European history, catastrophic famine. At least five million people died between 1931 and 1933 in the USSR. But instead of sending relief, the Soviet State made use of the catastrophe to rid itself of a political problem.

In "Red Famine", Anne Applebaum argues that more than three million of those dead were Ukrainians who perished not because they were accidental victims of a bad policy but because the state deliberately set out to kill them. Devastating and definitive, Red Famine captures the horror of ordinary people struggling to survive extraordinary evil [1].

Moreover this author sees a great relationship between the revolution of 1917 and catastrophic Ukrainian famine. Stalin himself during the events of 1917 was a Commissar for Nationalities. Ukraine was in the sphere of his responsibility. When in 1932 he considered the problem of hunger, the crisis that arose due to collectivization, it came to his head that it was an "old second uprising" [1]. What Anne Applebaum draw attention to in her book is that Stalin used the famine in his favor to solve the so-called Ukrainian problem for himself. In particular - to eradicate the protest potential of the Ukrainian peasantry. Then there were repressions against representatives of the Ukrainian intelligentsia. The goal was to make it impossible for Ukraine to be a threat to the Bolsheviks.

According to historical surveys, Stalin was afraid of the call that Ukraine threw the Bolshevik revolution in $1917[5 ; 6 ; 7 ; 8]$. Initially, he was involved in attempts to destabilize the emergence of "mini-republics" in Ukraine itself (including in Donetsk). He was involved in attempts to undermine this national protests, because he feared that it would be a rival to the Bolshevik revolution. Further events are important to understand: Ukraine was vital for Stalin and Soviet State. The question of who will win in Kiev, after all, was existentially important for the Bolsheviks. They did not want the non-bolsheviks government in Ukraine from the very beginning. This was fundamentally important from the very beginning [10]

Documents demonstrate that there was another threat that Stalin saw in Ukraine. Not only the fear of losing Ukraine as a source of grain and agricultural produce - the Bolsheviks saw an ideological threat in Ukraine. Ukrainians who did not accept Bolshevism were a huge threat.
The Bolsheviks believed that there was much in common between Ukrainians and Russians - they had a lot in common with culture, many family ties, Ukraine was a part of the Russian Empire for a long time so if Ukrainians did not accept Bolshevism, this can undermine the success of Bolshevism as a whole. Therefore, in addition to fear of losing Ukraine as a source of grain, the Bolsheviks - and Stalin among them - saw an ideological threat [3].

Davies R., Wheatcroft S. book "The Years of Hunger: Soviet Agriculture, 1931-1933" examines the Soviet agricultural crisis of 1931-1933 which culminated in the major famine of 1933. The authors used Russian and Ukrainian central and local archives to assess the extent and causes of the famine. They reached the new conclusions on how far the famine was 'organized' or 'artificial', and compared it with other Russian and Soviet famines and with major twentieth century famines elsewhere.

Ukrainian famine is considered to be a part of the Soviet policy after 1917. The famine was one of two blows on Ukrainian sovereignty - at the level of repressions against the intelligentsia. Purges, arrests, executions of Ukrainian historians, writers, artists, musicians, scholars, educational elite, teachers and even members of the Ukrainian Center of the Communist Party, the harassment of anyone who was connected with the Ukrainian republic of 1917 - all these facts had a devastating effect and destroyed humanistic approach in the whole Ukrainian state - its education and social life [8; 9]. People who were patriots who dreamed of their state, which could pass their patriotism and enthusiasm to descendants - all this generation was destroyed. And a new generation that has come to replace the old one was very afraid. Terror also led to a new generation of political elites - completely loyal to the Soviet system, either on conviction or because of fear.

In the long run Ukraine lost its most patriotic and active citizens, and in return received frightened people [6]. I think this also affects the current situation. It is not a secret that Ukrainians are suspicious of the state, they are blocked from state bodies, and authorities are certainly neglected on the part of citizens. The idea - that the state serves the purpose only of oneself - comes from the 1930s. And therefore, not just insulting - it hurts modern Ukraine [1].

Conclusions. The conducted analysis of the Ukrainian famine from the point of view of history, literature and journalism, allows us to make the following conclusions: the problem of the national fear about the future of the Ukrainian state and personality in this society has arisen periodically since 1991. So we can assume that Ukrainians do not feel relations with their own state, moreover they do not feel the responsibility for what it does, and vice versa. We think that the roots of this are still in the far Soviet period of famine, repressions and war.Today Russia as the successor to the Soviet Union, has placed Ukrainian independence in its sights once more. Applebaum's, Dahlen's, Davies's, Wheatcroft's compulsively readable narratives recall one of the worst crimes of the twentieth century, and show how it may foreshadow a new threat to the political order in the twenty-first century environment.

Realization of the fact that Stalin's famine brought degradation and reduction in all spheres of peoples life: 
social, political, educational and economic make it possible to overcome some difficulties existing in Ukrainian community today, taking into account recommendations of both European and American experience, looking forward into the future sustainable growth.
The importance of this problem determines the necessity of its continuous study. We think that special interest deserves the problem of investigation of Stalin's repressions influence into the Ukrainian system of education.

\section{REFERENCES}

1. Applebaum A. Red Famine. Stalin's war on Ukraine / Ann Applebaum. - 2017. - N.Y: Anchor Books. -520 p.

2. Hroch, M. Comparative Studies in Modern European History: Nation, Nationalism, Social Change / Miroslav Hroch. 2007. - Aldershot, UK: Ashgate Publishing Limited. - 336 p.

3. Dahlen M. Socialism, Fascism, and the Tyranny of Big Government / Michael Dahlen. - 2017. - Kindle edition. - 345 p.

4. Davies R., Wheatcroft S. The Years of Hunger: Soviet Agriculture, 1931-1933 // R. W. Davies and Stephen G. Wheatcraft. - 2004. - UK: Palgrave Macmillan. - 555 p.

5. Marples, D. R. Holodomor: Causes of the 1932-1933 Famine in Ukraine / David Roger Marples. - 2011. - Saskatoon: Heritage Press. - P. 105

6. Martin T. The Affirmative Action Empire: Nations and Nationalism in the Soviet Union, 1923-1939 / Terry Martin. 2001. - Cornell University Press. - 496 p.

7. Ogienko O. Model of Professional Teachers Competences Formation: European Dimension // Ogienko O., Rolyak A. // TEPE 3rd Annual Conference Teacher Education Policy in Europe:Quality in Teacher Education, May 2009, Umea University, Sweden, Proceedings. - [Online]. - Available:

http://tepe.wordpress.com/proceedings/tepe-2009proceedings.

8. Roliak A. Gulag as a Part of the "Great Terror": From the Point of View of the Famous Eyewitnesses / Angelina Roliak // Політичні репресії в Радянській Україні у 1930-ті рр.: матеріали всеукраїнської науково-практичної конференції, приуроченої до 80-ої річниці «Великого терору 1937 1938 рр.» та «Дню пам'яті жертв голодоморів». - Камянець-Подільський. - 2018. - Р. 34-38.

9. Roliak A.O. Reforms in teacher education system: Danish experience in Ukrainian environment // Humanities and Social Sciences in Europe: Achievements and Perspectives. The 1st International symposium proceedings. - 2018. Berlin: Premier Publishing s.r.o.. - C. $70-78$.

10. Serbyn R. The Ukrainian Famine of 1932-1933 as Genocide in the Light of the UN Convention of 1948: The State of the Question / Roman Serbyn // The Ukrainian Quarterly. - Vol. LXII. - No. 2. - 2006. [Virtual Resource] - Access Mode: URL: http://www.archives.gov.ua/Sections/Famine/Serbyn2006.php 